\title{
Geotechnical and Structural Aspect of 2015 Gorkha Nepal Earthquake and Lesson Learnt
}

\author{
Keshab Sharma ${ }^{1}$, Mandip Subedi ${ }^{2}$, Indra Prasad Acharya ${ }^{2}$, Bigul Pokharel ${ }^{3}$ \\ ${ }^{1}$ Department of Civil and Environmental Engineering, University of Alberta, Edmonton, AB, Canada \\ ${ }^{2}$ Department of Civil Engineering, Institute of Engineering, Pulchowk Campus, Nepal \\ ${ }^{3}$ National College of Engineering, Tribhuvan University, Lalitpur, Nepal \\ Corresponding author: keshab.sharma@gmail.com
}

Received: Jan 28, 2017 Revised: May 20, 2017 Accepted:May 27, 2017

\begin{abstract}
An earthquake of moment magnitude $\left(M_{w}\right) 7.8$ struck the central Nepal at 11:56 am on April 25, 2015. More than 9,000 people were killed and thousands of residential buildings, and hundreds other structures were also destroyed. An aftershock of moment magnitude $\left(M_{w}\right) 7.3$ hit northeast of Kathmandu on May 12 after 17 days of main shock which caused additional damages. Immediately after the earthquake, authors undertook a field investigation and visited the affected areas. Strong motion records from both earthquakes and their impacts on structures as well as geotechnical issues are presented in this paper. Most of the structures in Nepal are made of adobe, unreinforced masonry, and reinforced concrete. Failure mechanisms of those buildings are briefly explained in this paper. Geotechnical aspects such as soil liquefaction, slope failures, settlement and lateral spreading, and site amplification effects that considerably influenced the damage patterns at many areas are briefly discussed as well. The lessons learnt from this earthquake are also summarized in this paper.
\end{abstract}

Key words: Gorkha earthquake, field investigation, structural aspect, geotechnical aspect, local site effect

\section{Introduction}

A destructive earthquake of moment magnitude $\left(M_{w}\right) 7.8$ hit the central Nepal on April 25, 2015 at 11:56 a.m. local time. The epicenter of the earthquake located near Baluwa, Gorkha (N: $28.1470^{\circ}$; E: $\left.84.7080^{\circ}\right) 77 \mathrm{~km}$ northwest of Kathmandu. The focal depth of the earthquake was approximately $13 \mathrm{~km}$ [26]. A big aftershock of $M_{w} 7.3$ occurred in the northeast of Kathmandu on May 12, having the epicenter in Kodari region (N: $27.8368^{\circ}$; E: $\left.86.0772^{\circ}\right)$, and caused additional damage to northern central Nepal. More than 800,000 houses were damaged or destroyed. Out of Nepal's 75 districts, 31 were deemed most affected, and out of that number 14 districts were severely affected. Destruction is widespread; residential and government buildings, heritage sites, schools and health facilities were severely hit. Post Disaster Needs Assessment (PDNA) estimates that Nepal's financial losses from the earthquake are US\$7.06 billion, which is about $30 \%$ of the country's GDP [13]. Different government and non-government sources refer to estimated amount of 7 billion US Dollars required for the whole reconstruction process [13]. These seismic events in Nepal were the strongest after the 1934 earthquake that was located northeast of Kathmandu [4]. 
As of January 30, 2017, more than 465 aftershocks with a magnitude above 4 had been observed, 49 with a magnitude above 5 , and 5 above 6 [8].

As 2015 Gorkha earthquake in the Nepal was the strongest after the 1934 earthquake, the performance of the infrastructures during the earthquake in Nepal is poorly understood. Though Rana [14] and Pandey et al. [10] summarized the damages in Kathmandu Valley and nearby region caused by the 1934 earthquake, characteristics of earthquake, and structural and geotechnical aspect of the earthquake were not documented. Poudyal et al. [12] conducted micro-tremor study to characterise the soil response of Kathmandu Valley during the earthquake. Subedi et al. [23] studies the liquefaction potential of soil in Kathmandu Valley using SPT-N value. Jaishi et al. [5], Chaulagain et al. [1], and Parajuli et al. [11] studied the performance of buildings in Kathmandu Valley based on site-specific ground motions. Shakya et al. [15] reported the performance of the buildings during the September 18, 2011, earthquake of $M_{w} 6.9$ in eastern Nepal. However, the behavior of structures and soils in Nepal including Kathmandu Valley subjected to a major earthquake is poorly understood or investigated. For this reason, post-earthquake reconnaissance activities that studies both structural and geotechnical aspect of the earthquake and provide case studies are of the same significance as research activities for researchers, engineers, policy-makers, and the society in general of Nepal and other countries.

A field reconnaissance was carried out by the authors immediately after the earthquake. Figure 1 shows the survey routes, locations of investigation sites during the reconnaissance study. The main purpose of this paper is to record and comment upon the causes of the various types of structural and geotechnical damages observed and to determine what lessons can be learnt from this earthquake. It presents the characteristics of ground motions, structural and geotechnical aspect of the earthquake with prime emphasis on failure mechanisms of structures, liquefaction, settlement and lateral displacement, and local site conditions and their role on the degree of damages. The paper offers a number of case studies of structural and geotechnical damages. Finally, lessons learnt from this earthquake are summarized in this paper.

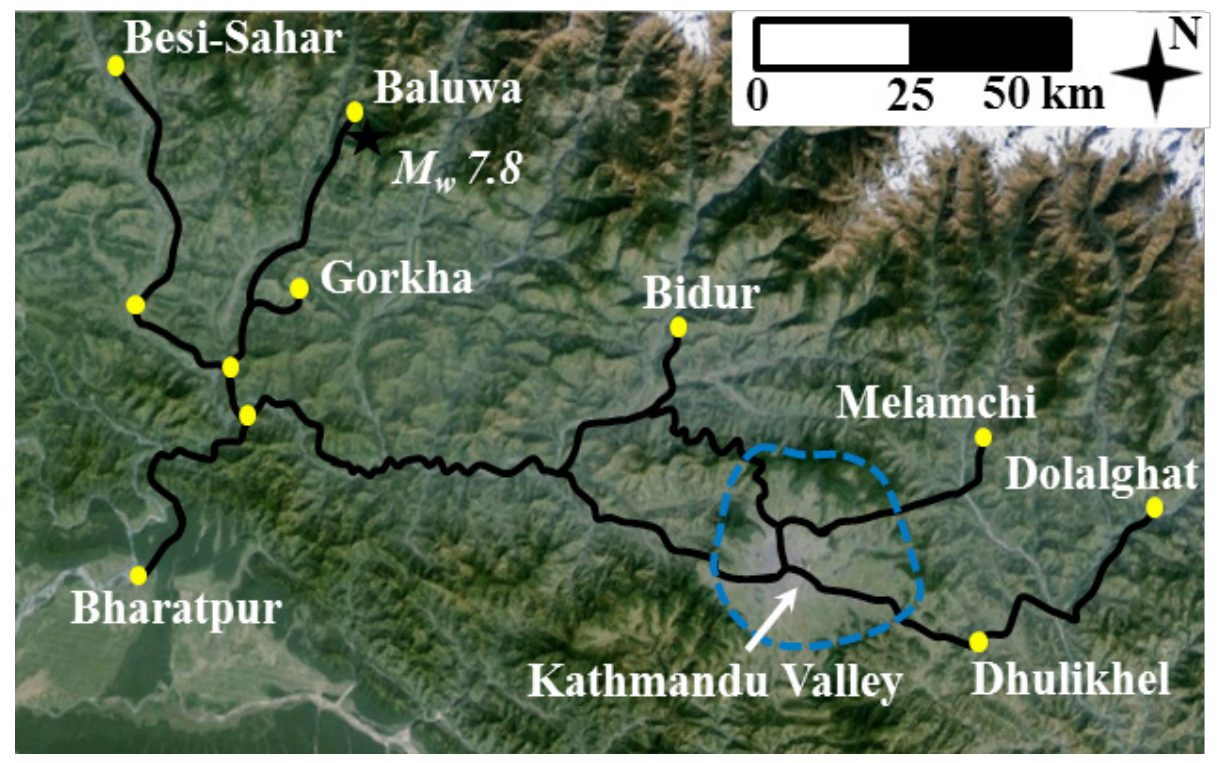

Fig. 1: Survey routes, locations of investigation sites that are referred in this report and the epicenters of the main shock. 


\section{Ground Motions and Response Spectra}

Strong ground motions recording at KATNP and KTP station are presented in this section. KATNP station was established by US Geological Survey (USGS) at Kanti Path, Kathmandu (N: $27.7120^{\circ}$, E: $85.3160^{\circ}$ ) while KTP station (N: $27.68216^{\circ}$, E: $\left.85.27259^{\circ}\right)$ was installed by Tribhuvan University, Nepal, and Hokkaido University, Japan [24]. The KATNP station is located on the top of a thick soil layer of 200 to $300 \mathrm{~m}$ thickness. The KATNP station is $77 \mathrm{~km}$ southeast of main shock epicenter and $75 \mathrm{~km}$ southwest of the aftershock epicenter. The KTP station is located on the rock outcrop at $75.8 \mathrm{~km}$ from main shock epicenter and $5 \mathrm{~km}$ southwest of KATNP station. Critical parameters of the main shock and May 12 aftershock are summarized in Table 1.

The E-W, N-S and vertical components of the accelerograms of the main shock at KATNP and KTP are shown in Fig 2. Figure 2 also shows the E-W, N-S and vertical components of the accelerograms of the $M_{w} 7.3$ aftershock at KATNP. The peak ground accelerations (PGA) of the main shock in horizontal direction are $164 \mathrm{~cm} / \mathrm{sec}^{2}$ and $241 \mathrm{~cm} / \mathrm{sec}^{2}$ at soil site (KATNP) and rock site (KTP), respectively. Time histories in Figure 3 demonstrate that the horizontal accelerograms at KATNP contained long period ground motion of about $5 \mathrm{sec}$ which may be attributed to the response of the Kathmandu basin. Although the long-period component is large, the shorter-period component $(1-2 \mathrm{sec})$ is relatively small, resulting in a peak ground acceleration value of $184 \mathrm{gal}$ in vertical directions. As noted, observations at valley sites (KATNP) reveal PGA amplifications relative to the hard-rock reference site (KTP). These amplifications are probably due to sediment amplification and basin effects.

The velocity time histories of the main shock and aftershock are shown in Fig. 2. The highest peak ground velocity as $107.3 \mathrm{~cm} / \mathrm{sec}$ was given by the EW component recorded at KATNP. While the peak ground velocity as $35.78 \mathrm{~cm} / \mathrm{sec}$ was given by vertical component of the ground motion at KATNP. It is shown the peak ground velocity at rock site (KTP) was smaller than the peak ground velocity at soil site (KATNP) due to the local site effect. As in accelerograms, the ground velocities at the soil sites had long duration with conspicuous long-period oscillations. The peak ground velocity of NS component of ground motion at KATNP station due to $M_{w} 7.3$ aftershock was about $15 \mathrm{~cm} / \mathrm{sec}$. The displacements at KATNP station due to main shock were 3-5 times higher than the displacement at KTP station from same seismic event. The maximum displacement at KATNP station due to $M_{w} 7.3$ aftershock was about $8 \mathrm{~cm}$ given by EW component of ground motion (Fig. 2).

The 5\%-damped acceleration response spectra (ARS) of the main shock earthquake at KATNP and KTP are compared with the designed response spectrum defined by Nepal National building code [9] in Fig. 3a. It is found that both N-S and E-W components at KTP have a peak at $0.25 \mathrm{sec}$ while the N-S component at KATNP has two prominent periods at $0.47 \mathrm{sec}$ and $5 \mathrm{sec}$ and E-W component has one peak at $5 \mathrm{sec}$. The acceleration records at soil site (KATNP) are broadband and contain the long-period components at $5 \mathrm{sec}$. The characteristics of the ground motions are the result of the effects of the thick, soft sediment in the valley, where the KATNP is located. Figure $3 \mathrm{~b}$ shows the $5 \%$-damped ARS of the $M_{w} 7.3$ aftershock at KATNP. N-S components of aftershock at KATNP has a peak at 0.35 second while the E-W components at $1 \mathrm{sec}$. Both E-W and $\mathrm{N}-\mathrm{S}$ components of main shock have the secondary peaks at about $5 \mathrm{sec}$ whereas the aftershock components do not show the peaks at $5 \mathrm{sec}$. The Fourier amplitude spectra of the accelerograms of main shock recorded at KATNP and KTP shown in Fig. 3c. Spectral ordinates increase with 
frequency from 0.05 to about $0.2 \mathrm{~Hz}$, are relatively level to about $0.25 \mathrm{~Hz}$, and generally decrease above $0.3 \mathrm{~Hz}$, due to attenuation. At frequencies above $2 \mathrm{~Hz}$, the spectra from the main shock are similar regardless of stations site condition.
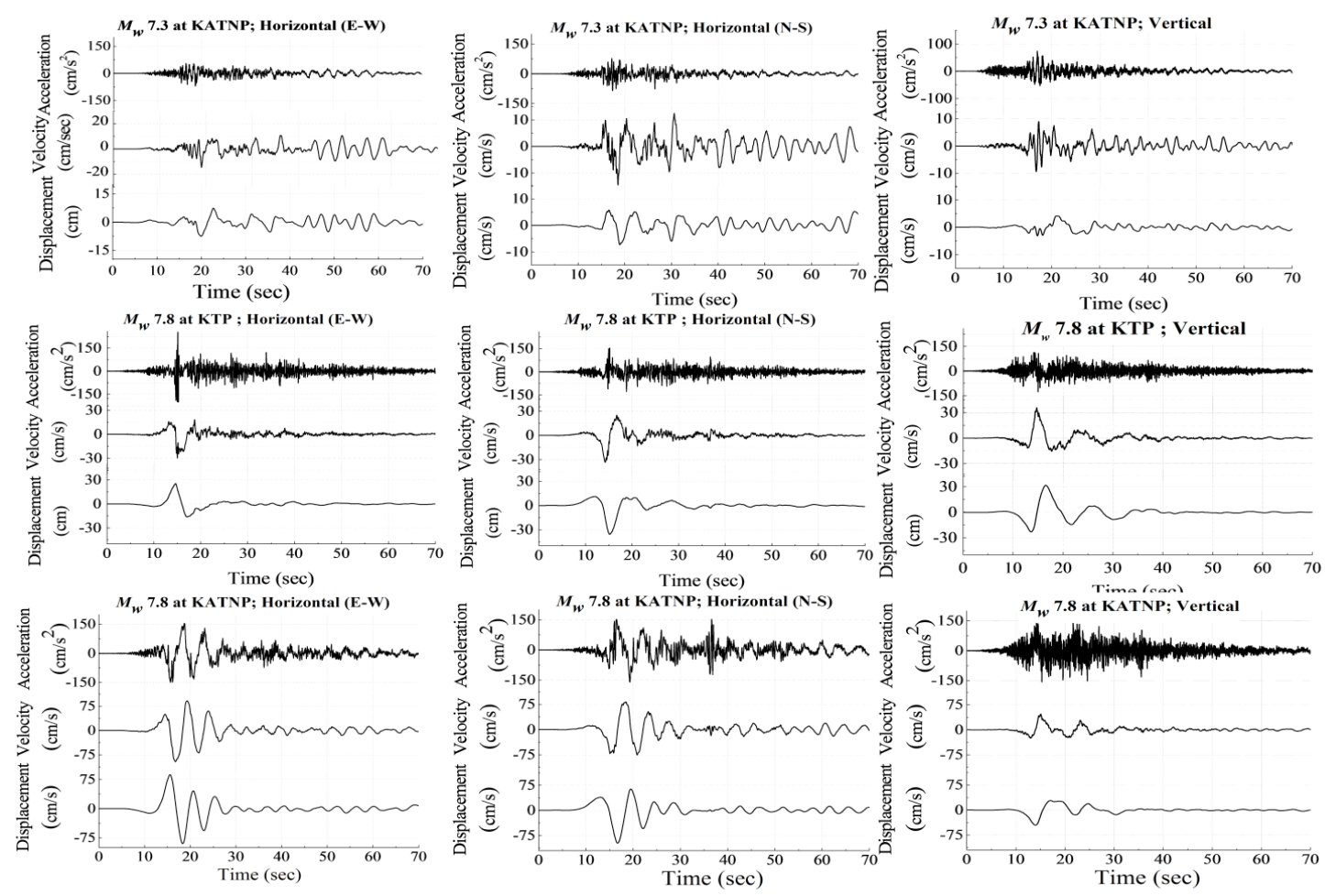

Fig. 2: Recorded accelerograms at KATNP and KTP station [13], velocity and displacement time histories of the $M_{w} 7.8$ main shock at KATNP and KTP station and $M_{w} 7.3$ aftershock at KATNP station.

Spectral acceleration ratio, $\alpha$, (ratio of the ARS at the soil site to the ARS at the rock site for the given period) is analysed and shown in Fig. 3d. It is shown that the ground motions at the KATNP site were strongly influenced by the local site condition at long periods. At $5 \mathrm{sec}$ period, the spectral acceleration ratio, $\alpha$, in E-W direction reaches 5.5 which is considered a significant amplification, while in N-S direction, $\alpha$ reaches 2.8 .

Table 1. Key characteristics of $M_{w} 7.8$ main shock and $M_{w} 7.3$ aftershock

\begin{tabular}{|c|c|c|c|c|c|c|c|c|}
\hline Station & Date & $\begin{array}{c}\text { Time } \\
(\text { Local })\end{array}$ & $\begin{array}{c}\text { Focal Depth } \\
(\mathrm{km})\end{array}$ & $\begin{array}{c}\mathrm{NS} \\
\left(\mathrm{cm} / \mathrm{s}^{2}\right)\end{array}$ & $\begin{array}{c}\text { EW } \\
\left(\mathrm{cm} / \mathrm{s}^{2}\right)\end{array}$ & $\begin{array}{c}\text { Vertical } \\
\left(\mathrm{cm} / \mathrm{s}^{2}\right)\end{array}$ & $\begin{array}{c}\text { Latitude } \\
\left(\mathrm{N}^{\circ}\right)\end{array}$ & $\begin{array}{c}\text { Longitude } \\
\left(\mathrm{E}^{\circ}\right)\end{array}$ \\
\hline KATNP & $4 / 25 / 15$ & $11: 56$ & 15 & 164 & 158 & 184 & 28.15 & 84.71 \\
\hline KATNP & $5 / 12 / 15$ & $12: 50$ & 15 & 87 & 72 & 75 & 27.84 & 86.08 \\
\hline KTP & $4 / 2 / 15$ & $11: 56$ & 15 & 241 & 150 & 121 & 28.15 & 84.71 \\
\hline
\end{tabular}



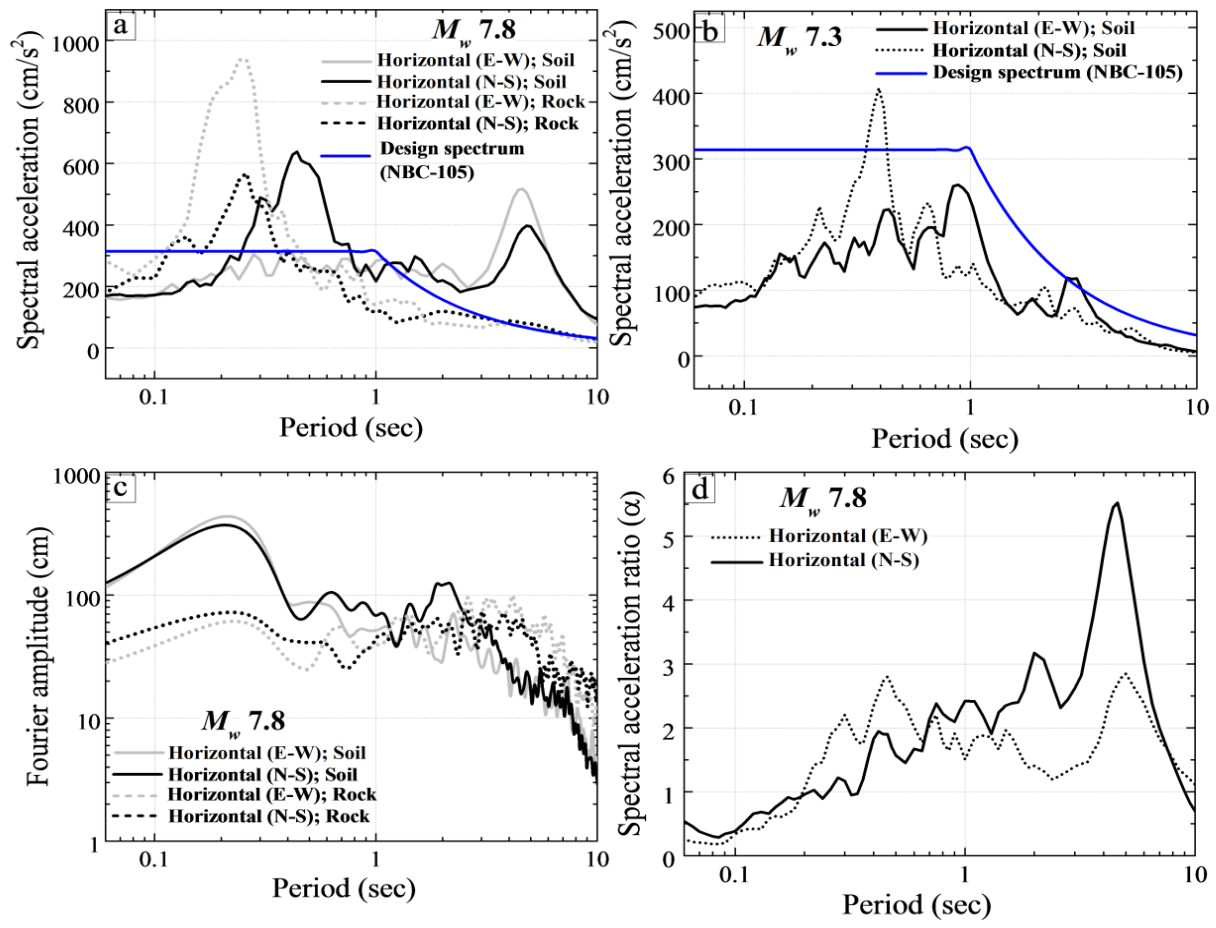

Fig. 3: (a) 5\%-damped acceleration response spectra (ARS) of the main shock motions at soil (KATNP) and rock (KTP) stations, (b) 5\%-damped ARS of the $M_{w} 7.3$ aftershock motions at KATNP, (c) Fourier amplitude spectra of the main shock motions at soil (KATNP) and rock (KTP) stations, and (d) ARS amplification ratio of the main shock soil motions at KATNP with respect to the outcrop motion at KTP.

\section{Structural Aspect of the Earthquake}

This section is intended to describe the damages associated with buildings, bridges and lifeline structures. Most of the buildings in the urban areas of Nepal are either RC (reinforced concrete) moment resisting frame structures with infill walls consisting of unreinforced brick masonry in cement mortar or load-bearing brick masonry with mud or cement mortar. Reinforced concrete shear wall construction is rare. But in case of rural areas of Nepal, buildings are built using materials found in local areas i.e. adobe, bricks, and stones. Stone-masonry structures in the rural areas were observed to have made of undressed stones bonded with or without mud mortar. RC bridge is very common in Nepal with very limited streel bridge.

\subsection{Damages to RCC Buildings}

In Nepal, typically RC buildings have burnt clay bricks as wall filling materials. Noticeable features of this type of buildings in Nepal are: (i) absence of lintels above doors and windows (ii) floating columns in upper storey, (iii) intermediate soft storey in multi-storey buildings, and (iv) poor reinforcement detailing [19]. 

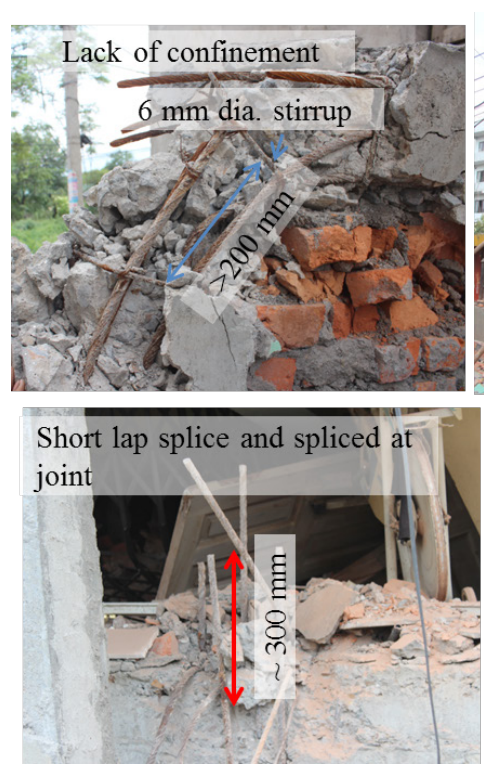

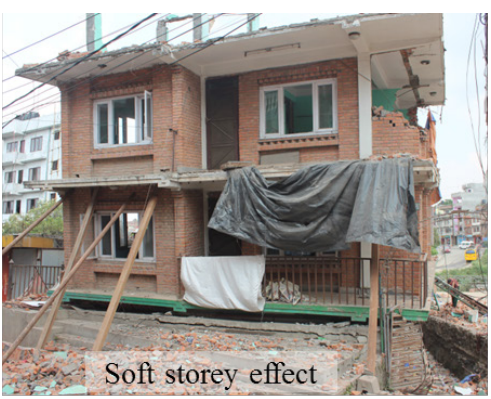

Poor quality concrete and insufficient stirrups

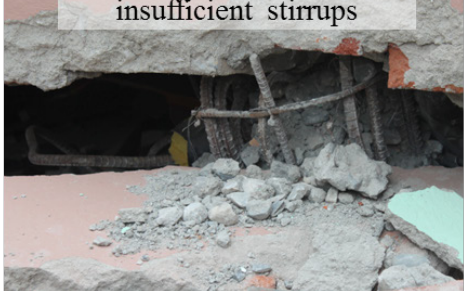

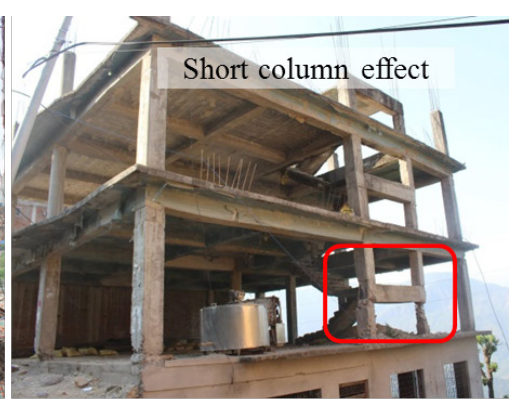

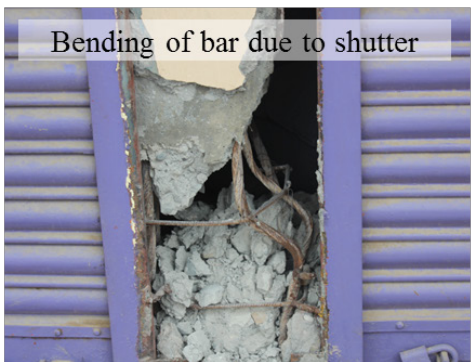

Fig. 4: Typical failures observed in RC buildings.

The primary mechanism of collapse was observed as shear failure caused by the absence of stirrup at or near the beam-column joint, wide spacing of the stirrups, buckling of longitudinal rebar, and the poor confinement of the core concrete. Embedded hook angle and length was not enough for stirrups to be effective. Thin column section $(230 \mathrm{~mm} * 230 \mathrm{~mm})$ was another reason of the damage. Insufficient longitudinal reinforcement (less than 1.0\%) in columns and short lap splices of main bars contributed to the severe damages or collapses of buildings. Failures and damages of reinforced concrete buildings due to the soft stories were observed because of elimination of infill wall due to social or commercial needs (Fig. 4). Short column failures were widely observed during the field assessment. Short column is generally formed due to intermediate staircase landing in between two floors (Fig. 4) and partial infilled frames to fulfill functional requirement of lighting and ventilation. Many houses with rolling shutters at the ground level were severely damaged. The majority of rolling shutters were installed inappropriately, such that the adjacent RC columns were damaged; main reinforcements were exposed and welded with the shutter guide. Low quality concrete and more workmanship were manifested in the affected area and undermined the seismic performance of reinforced concrete buildings [19]. Damage and failures related to strong beam weak columns mechanism were observed (Fig. 5). In Kathmandu Valley, many buildings are constructed closely and therefore are particularly susceptible to the pounding damages. Water tank on the top of buildings are not considered in designed and suffered from severe damage (Fig. 5). Typical failures observed in RC buildings are shown in Figs. 4 and 5. 

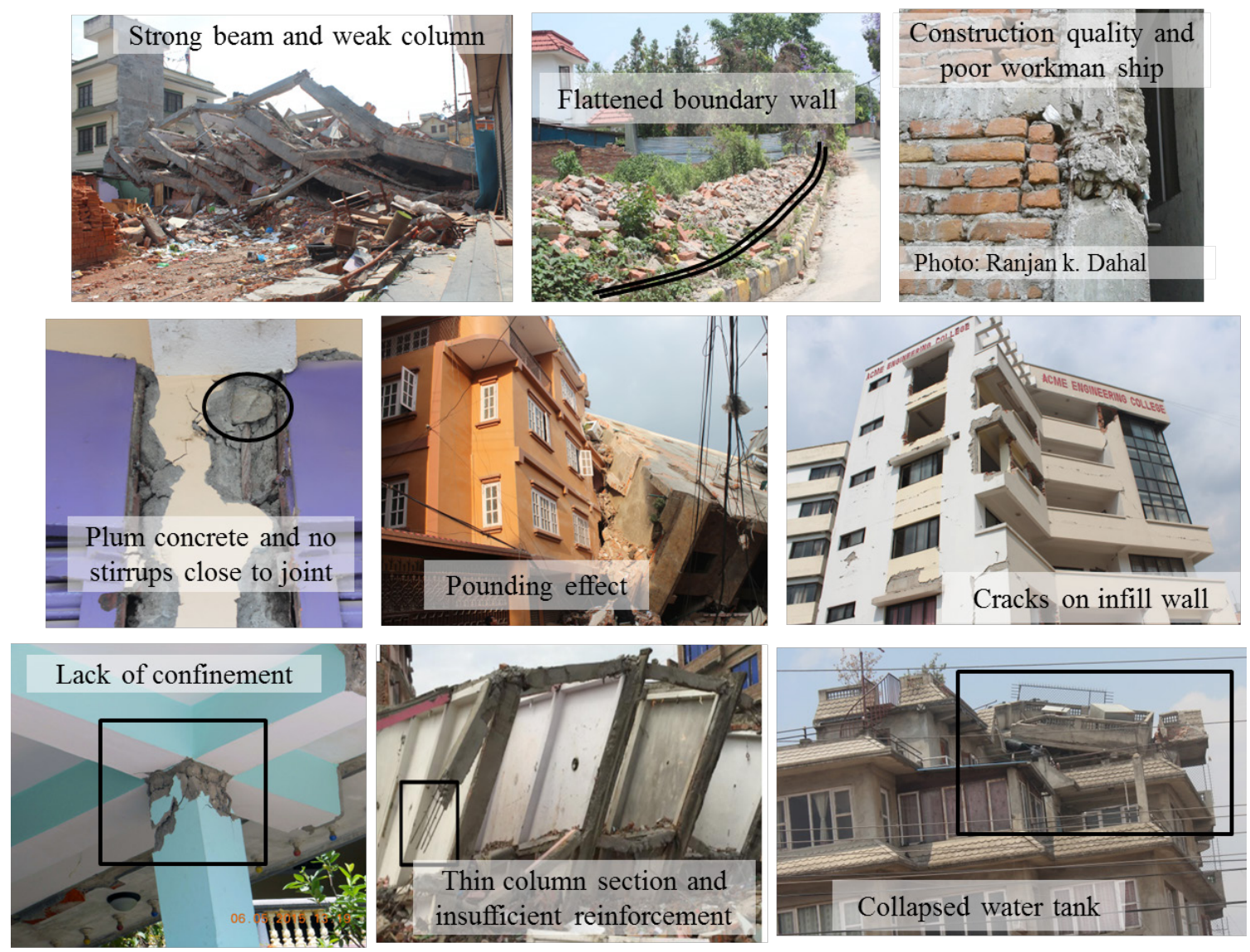

Fig. 5: Typical failure observed in RC building during the reconnaissance.

\subsection{Damages to Masonry Buildings}

The causes of the damage of masonry buildings were observed to be poor construction detailing, poor masonry material properties, irregularly shaped stones having smooth surfaces, weak structural walls, unconfined gable walls, large openings on the wall and cracks at the corners of windows and doors. The masonry in these buildings was unreinforced and the walls were not tied to each other or to the floors and roofs. Earthquake-resistant features such as horizontal ties at various levels and stones at the corners are generally not provided in such constructions. Minimum reinforcement measures using through stones in the walls or using horizontal and vertical bands significantly improved the seismic performance of masonry buildings [19]. The typical failures observed during the reconnaissance study are shown in Fig. 6. 


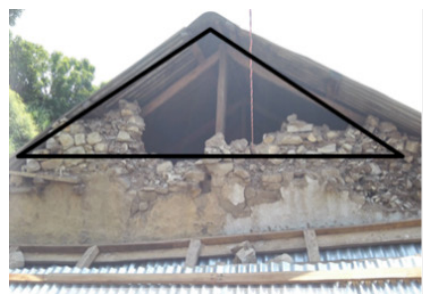

Gable wall failure
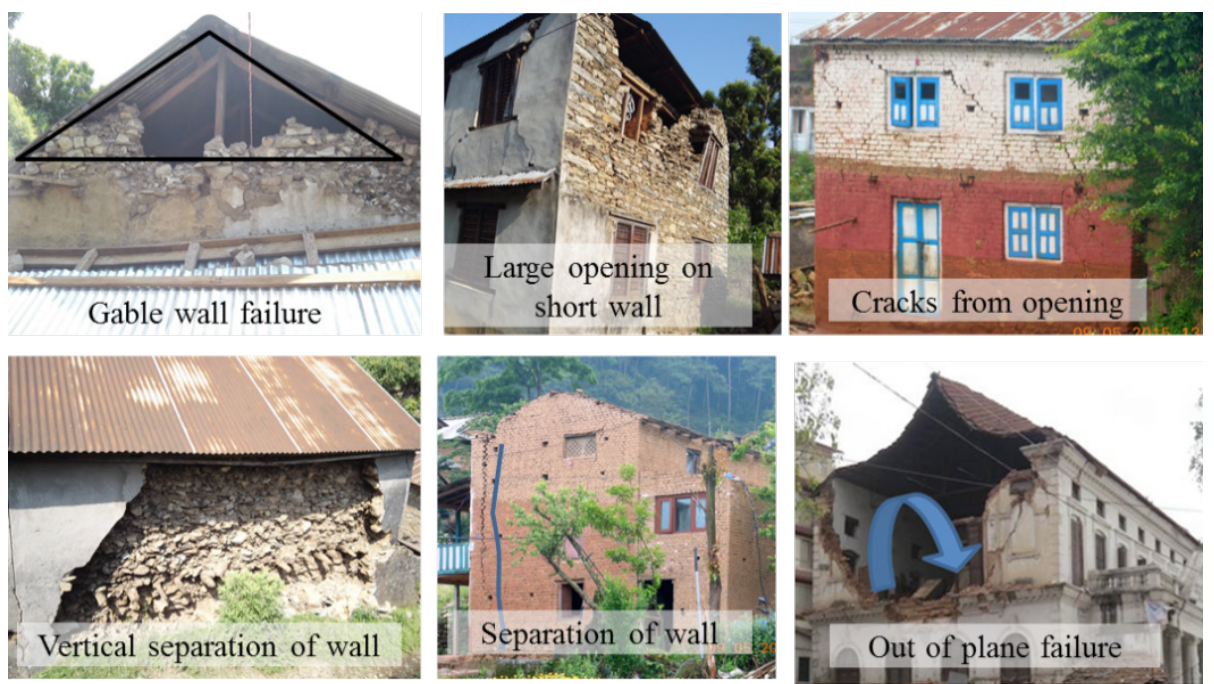

Fig. 6: Typical failures observed in masonry buildings.
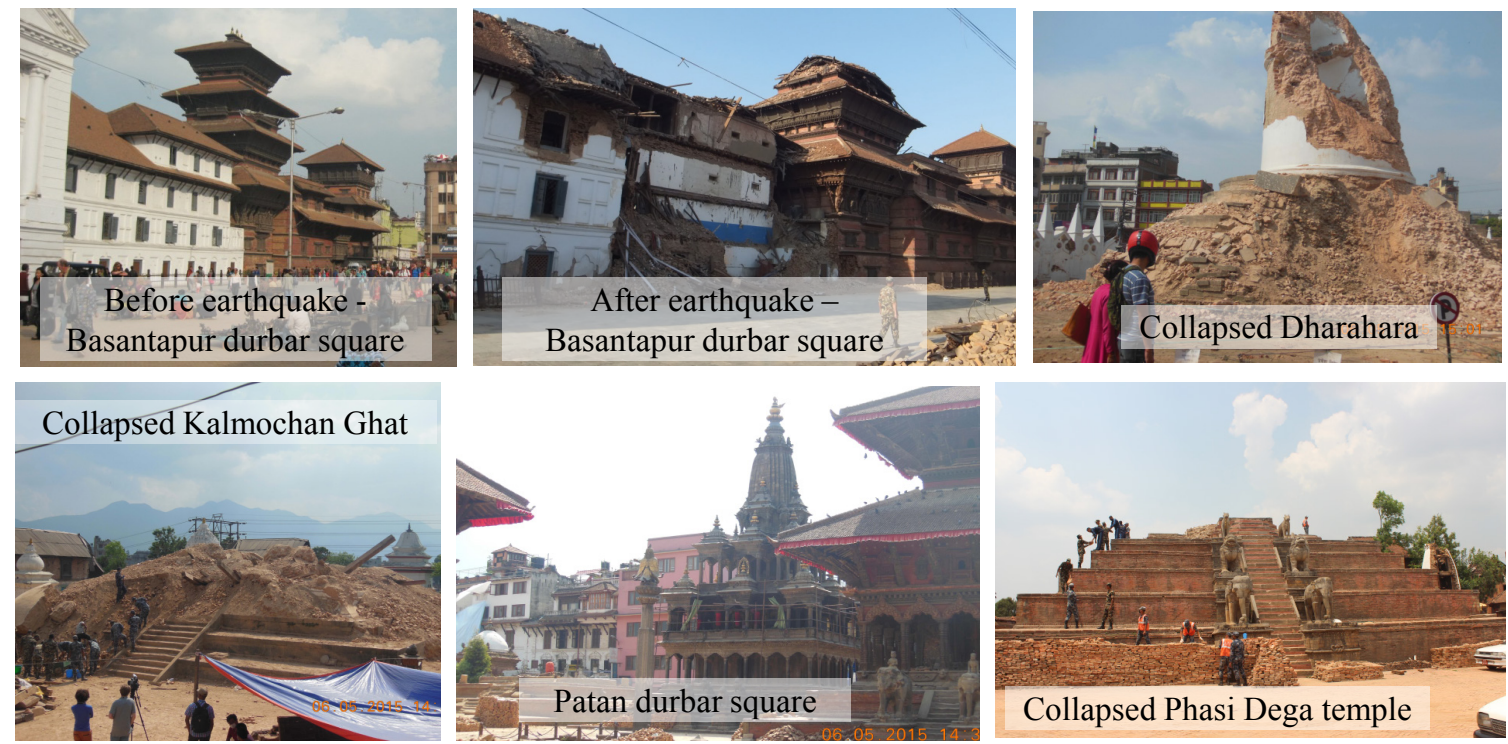

Fig. 7: Typical failure observed in heritage structures in Kathmandu Valley.

\subsection{Damages to Heritage Structures}

Many monuments and religious structures in Kathmandu Valley were destroyed by the earthquake. Temples in durbar square of Basantpur (Kathmandu), Patan, and Bhaktpur constructed several centuries ago were broken down during the earthquake (Fig. 7). Dharahara Tower, which was 9 storey high and built in 1832, was completely destroyed (Fig. 7). Most of ancient monument structures were of masonry type using bricks and earth mortar (mainly clayey mud) as a bondingagent, with walls being capable of withstanding vertical static gravitational loads but not horizontal dynamic loads. According to the preliminary report of Department of Archaeology, the earthquake 
has affected as many as seven hundred and forty-five monuments of twenty districts [7]. Out of them, one hundred and thirty-three monuments have completely collapsed, ninety-five monuments have partially collapsed and five hundred seventeen monuments are partly damaged. It is important to notice that the damage in Patan Durbar Square was observed minor compared to other historical monuments, due to the maintenance and retrofit activities completed prior to the earthquake. The retrofitting consisted of improving the structural integrity of horizontal floor and roof diaphragms by anchoring them to the supporting walls, replacing rotten wooden elements, strengthening frames, and improving the anchorages of both structural and non-structural elements [7].

\subsection{Damages to School Buildings}

Many school buildings even in urban area built before the 1980s are unreinforced masonry buildings. Masonry buildings in Nepal were not designed and constructed in accordance with the National building code [9] Nepal. School buildings in remote area are constructed of stone, and adobe; in place of adobe have a poor clayey mud mortar. Generally, stone-masonry structures in the area are of undressed stones with mud mortar (Fig.8). In many cases, buildings designed for residential purpose are being used for school building. About 8,200 school buildings were damaged and about 16,000 schools were severely affected by this earthquake. As the earthquake occurred on a Saturday (Only weekend in Nepal), there were not severe human casualties in these buildings. A series of school buildings that were retrofitted prior to the earthquake performed very well (Fig. 8).
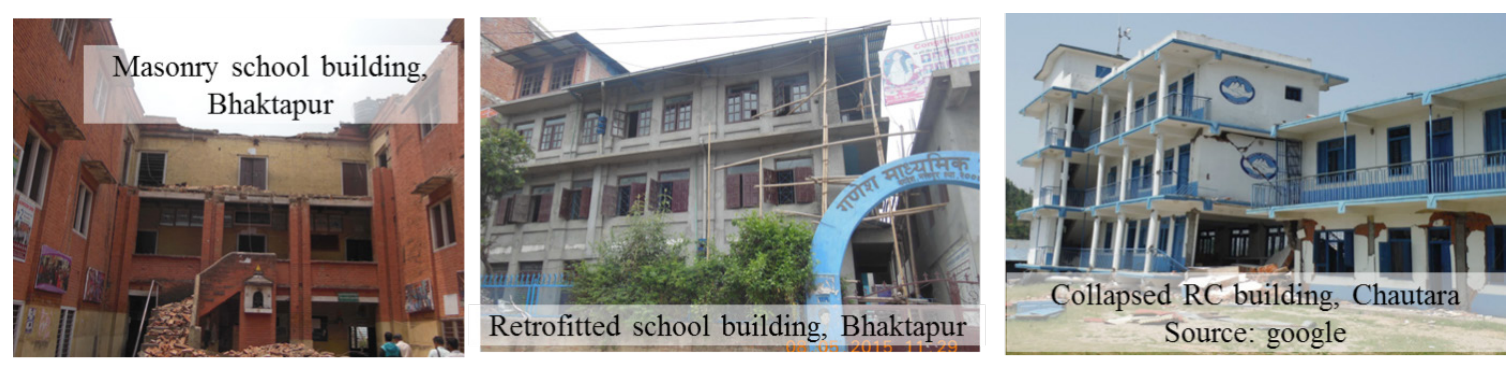

Fig. 8: Performance of the school building during the earthquake

\subsection{Damages to Bridge Structures}

About 350 bridges out of 1,800 bridges in Nepal are located in the affected area including 30 bridges in the Kathmandu Valley [18]. It was estimated that almost half of the bridges in the valley could be impassable during the moderate earthquake, as most of the bridges are in dilapidated condition. Dixit et al. [18] emphasised potential damages on bridge in Kathmandu Valley due to liquefaction. However, no single bridge has been reported damaged due to liquefaction. Most bridges investigated during the field reconnaissance suffered from minor damages on expansion joints and decks, while several decks were slightly displaced. For example, Teku Bridge (Fig. 9) over Bagmati River built in 1950 experienced the opening of expansion joints. The bridge appears to be functional despite that a nearby RC building collapsed [18]. Some overhead bridges in Kathmandu and Bhaktapur sustained severe damage; these structures can be operable after some repairs. Bridge shown in Fig. 10 is a newly constructed bridge ( 3 span and $75 \mathrm{~m}$ length) at the distance about $3 \mathrm{~km}$ from epicentre of $M_{w} 7.8$ earthquake, no cracks and settlement were found. 


\subsection{Damages to other Lifeline Structures}

This section intends to briefly explain the earthquake effects on lifelines, specifically on electricity, water supply and sewerage, telecommunications, and airports. As these services in Nepal were intermitted even before the earthquake and people are used to of the poor lifeline services, the effects of earthquake on the lifeline structures were not highlighted significantly [16].
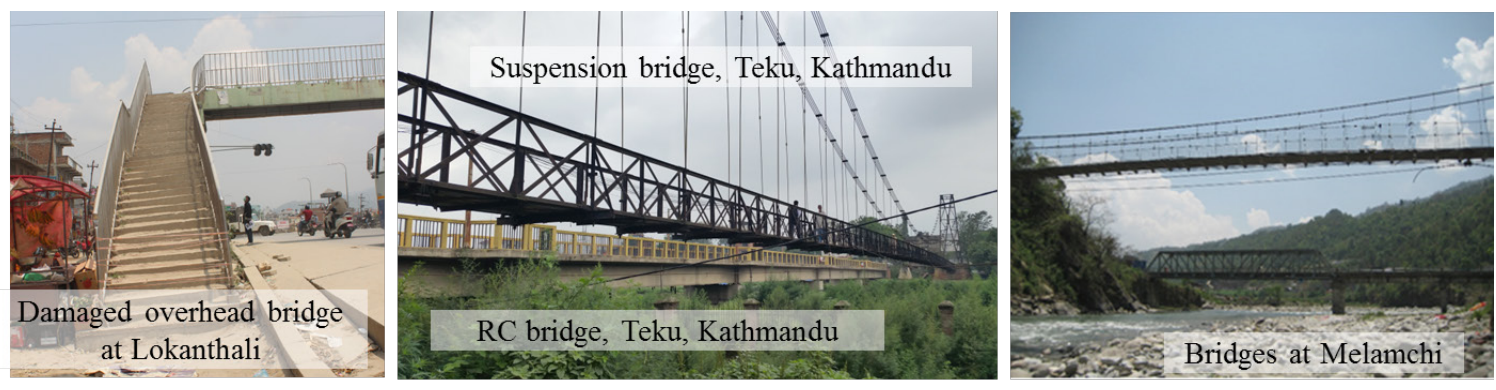

Fig. 9: Typical bridges investigated during the reconnaissance

In contrast to building structures, the hydropower plant, transmission system, substations, and switchyards performed well. However, damage of few transmission towers was reported. Electricity was resumed within 24 hours in devastated area except in some small areas. Some ongoing hydropower project such as Upper Tamakoshi suffered from severe damage and will be delayed at least 1-2 years for hydropower generation. Water supply and sewerage system has not developed comprehensively in Nepal expect in Kathmandu valley and some major cities. Even in Kathmandu Valley, water supply and sewerage system is in poor condition where Kathmandu Upatyaka Khanepani Limited (KUKL) operates and maintains the water supply and sewerage systems in urban areas. Water supply and sewerage system was disturbed for few days. As the more than half of population left Kathmandu Valley immediately after the earthquake, impact of earthquake damage to water supply and sewerage system was not to the expected extent. Damage to pipelines, water tanks and sewerage were reported at many places.

As of electricity, phone and mobile services were resumed within 1-2 days in most part of Kathmandu Valley. The internet was down in the Kathmandu Valley for about 24 hours because of power outages. The international link to India remained in service. However, many towers erected on the top of buildings were collapsed or severely damages as these buildings did not follow the seismic code. Tribhuvan International Airport (TIA) is only one international airport in Nepal that connects Nepal to other countries. Dixit et al. [3] had concluded that there are greater possibilities of soil liquefaction in Tribhuvan international airport (TIA) during an earthquake which means that the airport may also be cut off from access limiting emergency aid from outside. Unlike to the previous studies, there was minor non-structural damage but no structural damage to buildings, and no significant damage to the pavement surface of the runway, taxiway, and apron. However, the airport suspended operations immediately after the earthquake to assess the conditions of the airport and resumed within 24 hours. All domestic airports were functional as well.

\section{Geotechnical Aspect of the Earthquake}

This section is intended to describe the geotechnical aspect of the earthquake such as landslide, liquefaction, local site effects, and so on. Geotechnical problems encountered during reconnaissance study are mainly landslides, slope failure, liquefaction and lateral spreading and displacements. 
Effect of local site conditions on damage severity was also manifested during the reconnaissance, which will be discussed later.

\subsection{Landslides and Slope Failure}

Landslide is one of the most prevalent hazards in Nepal because of the active seismicity, great relief, intense monsoon rains, and accelerated erosion due to deforestation and rapid construction. About 3,600 landslides of small to mega scales were identified within $200 \mathrm{~km}$ of the epicenter after the main shock and $M_{w} 7.3$ aftershock, causing enormous economic and socio-environmental loss [2]. Most landslides were shallow, typically involving the top several meters of weathered bedrock, regolith, and soil [18]. Many of the landslides were still active during the field trip. Rock falls along Mugling-Narayanghat highway (Fig. 10), which was active since the main shock kept on obstructing the highway frequently.
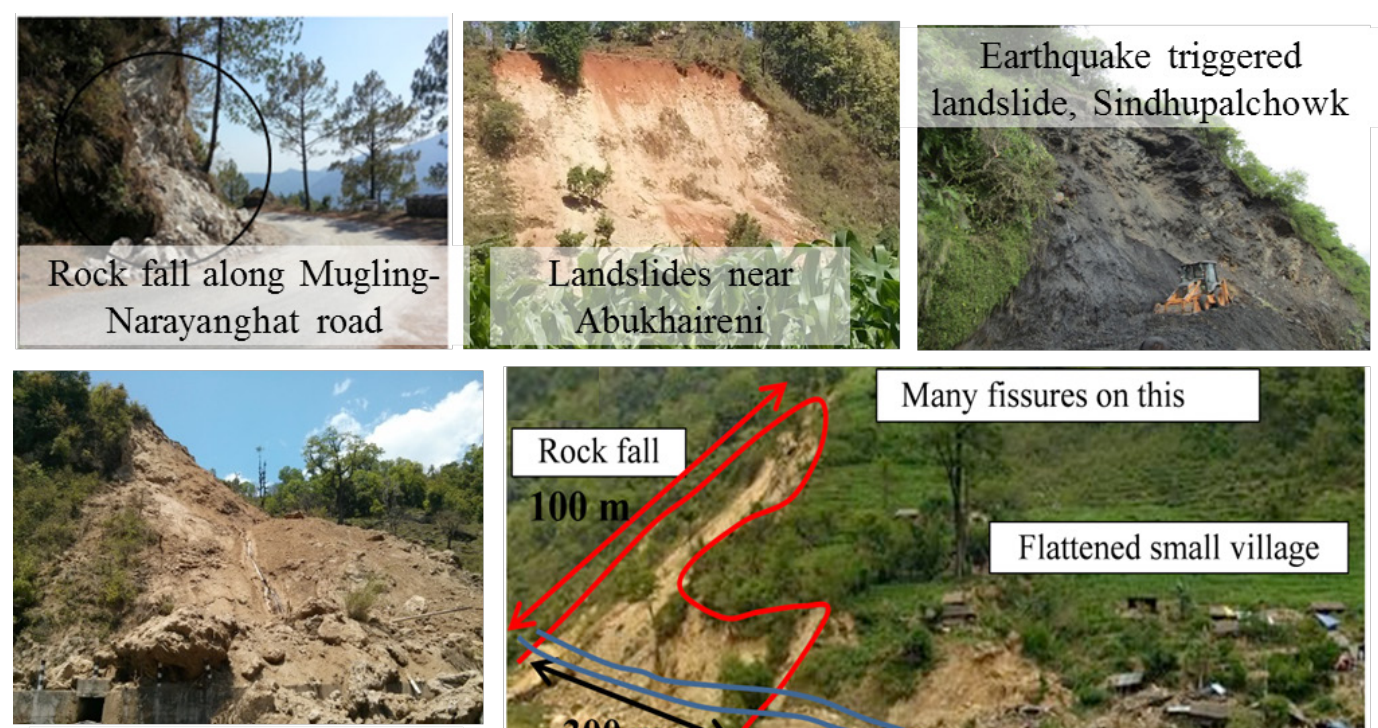

Buried micro-hydro near epicentre $(\sim 10 \mathrm{~km})$

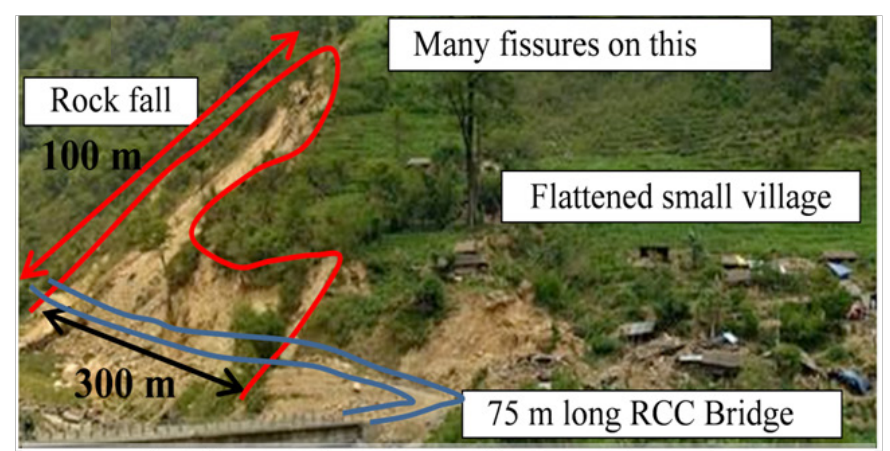

Rock-fall at Baluwa, Gorkha near by epicentre

Fig. 10: Earthquake triggered mass movement observed during the field visit

Numbers of slope failures were observed as authors travelled from Abukhaireni to Baluwa (a small village near the epicentre). A large number of steep slopes failed at shallow depth in the epicentral area, and their scale in terms of quantity and dimension tends to increase toward the epicentre. A micro-hydro was found buried into the landslides (Fig. 10) at a distance about $10 \mathrm{~km}$ from Baluwa toward Abukhaireni. A major rock fall was found near Baluwa village at the distance of $3 \mathrm{~km}$ from the epicentre of the main sock and obstructed the Abukhaireni-Daraudi link road (Fig. 10). A village on the left of rock fall was destructed. Fortunately, there were only minor cracks on the newly constructed reinforced concrete (RC) bridge near the rock fall. The road construction in hilly areas involves extensive stretches of cut and fills that excavates notches into the weathered bedrock on one side and fills the opposite side of the road. It was observed that many of the steep cuts and adjacent slopes failed along nearly every stretch of the road that occupies steep slopes. Furthermore, the outside margins of many of the roads failed or were extensively fissured because the fill was not sufficiently compacted during the construction [18]. Extensive ground fissures 
were found along the slopes at many places. $M_{W} 7.3$ aftershock had triggered landslides at Araniko highway and obstructed the vehicular movement for a couple of months. This aftershock also caused hundreds of landslides in central north of Nepal.

\subsection{Lateral Spreading and Settlement}

The earthquake had caused minimal lateral spreading and settlement. One of the most highlighted cases is the 6 lane highway at Lokanthali, as shown in Figure 11. 200-m-long embankment segment of the 6 lane Araniko highway suffered from substantial settlement of approximately $1 \mathrm{~m}$ due to the main shock, as shown in Fig. 11. Ground fissures, settlement, tilting of buildings and road pavement damage were observed in the surrounding areas (Fig. 12). As a result of the settlement, soil was used to fill the vertical gap immediately after the earthquake to build a temporary access as shown in Fig. 11. Ground fissures extended several hundred meters diagonally across the highway leading to the damage and tilting of many buildings and boundary walls (Fig. 12). Improper compaction, lateral spreading of side walls and subsidence of saturated soil beneath the embankments were the causes of the embankment settlement [18]. Apart from the subsidence, the embankment performed very well during the earthquake. Due to the critical importance of the 6 lane Araniko highway, detail geotechnical investigation shall be conducted to thoroughly understand the cause of the geotechnical issues observed.

Lateral spreading were minimal and were localized to the eastern edge of Kathmandu Valley. Longitudinal cracks on a compacted road embankment caused by the lateral spreading were found in Sinamangal (near airport), Kathmandu, and Kupondol, Lalitpur (Fig. 12). Lateral displacement of slope and deep-seated slides may be attributed to the crack on the ground surface.
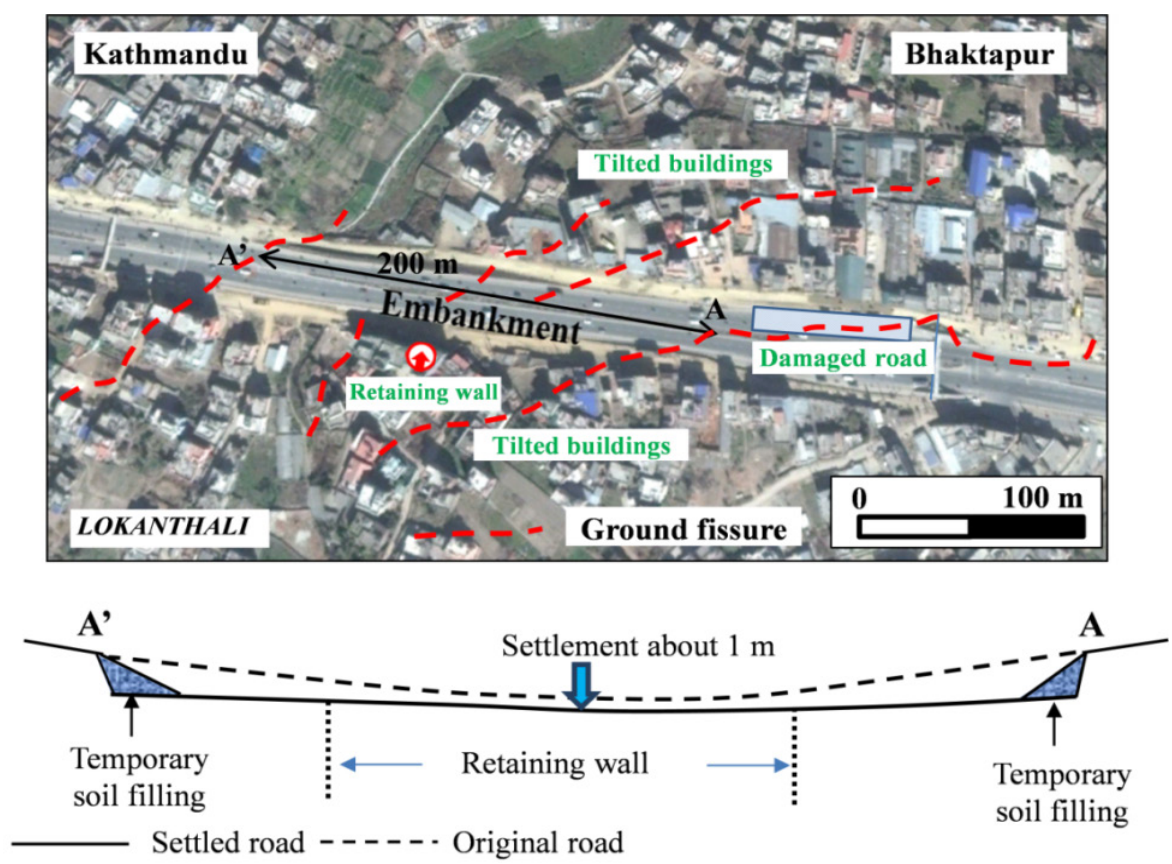

Fig. 11: Location of damage observed in Lokanthali along the Araniko highway (top) and longitudinal view of the subsidence of Araniko highway embankment (bottom) 

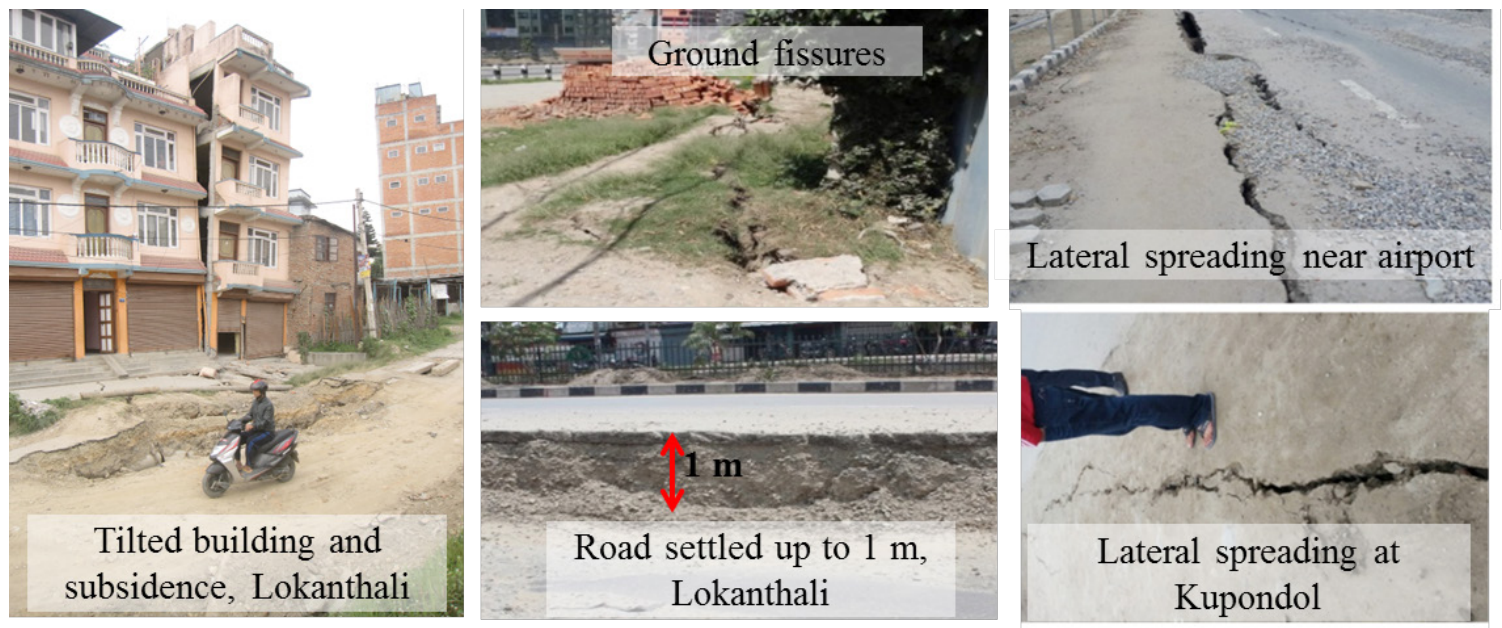

Fig. 12: Typical lateral spreading and settlement caused by the earthquake
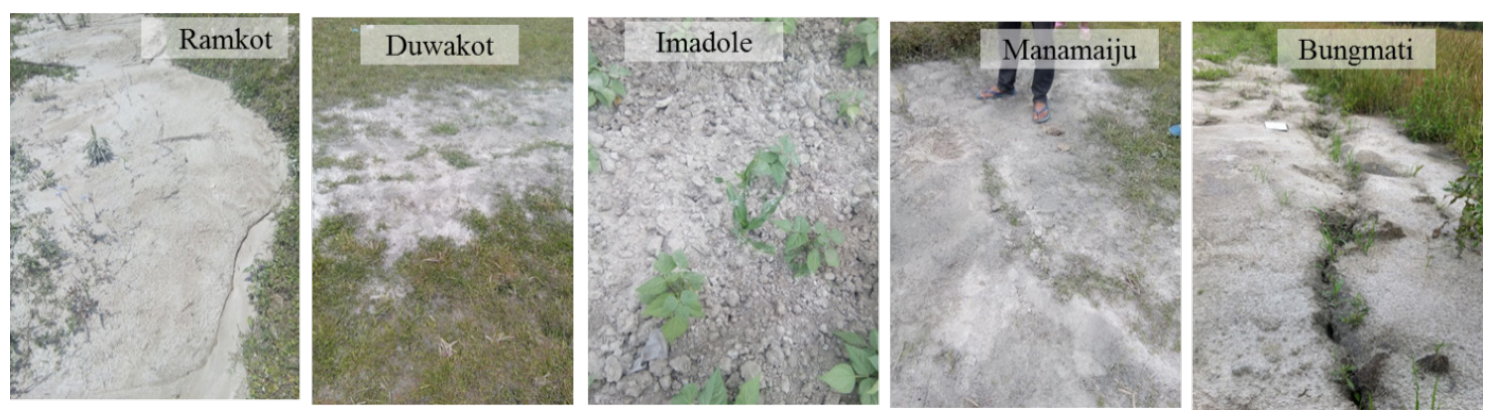

Fig. 13: Observed liquefaction at various locations in Kathmandu Valley

\subsection{Liquefaction}

As the Kathmandu valley deposits are composed mainly of sand, silt and clay layers with a shallow ground water table, liquefaction is highly anticipated. Extensive liquefaction was also reported in Tundhikhel area during the 1934 Nepal-Bihar earthquake [14]. Past research also highlighted the liquefaction vulnerability at many locations in Kathmandu Valley [6, 25]. However, unlike in previous major earthquakes, the liquefaction triggered by the Gorkha earthquake appears to be fairly limited and localized. This may be attributed to low amplitude ground motion and low ground water table at the time of earthquake event. The areas where liquefaction was observed are Ramkot, Manamaiju, Bungmati, Jharuwarasi, Hattiwan, Imadol, Mulpani and Duwakot [18, 20]. Sand boils were formed by freshly ejected sand forced out of over-pressurized ground surface. At most sites, sand was ejected to agricultural fields having thickness up to few centimeters (Fig. 13). The soil profile of the liquefaction affected areas comprises silty clay or silt on the top followed by low-plasticity silty clay locally known as black cotton clay $0.5-1.5$ thick and loose fine sand up to $3 \mathrm{~m}$ depth. These deposits coincide with shallow water table up to 1.3 to $4 \mathrm{~m}$ below ground surface. It was found that the ejected soil was fine sand containing 50\% non-plastic silt. Liquefactioninduced damage to structures in these areas was not found except buildings in some places tilted slightly. Incipient liquefaction was also observed at many places including Gongabu, Kaushaltar and Lokanthali. More details of the liquefaction caused by 2015 Gorkha earthquake can be found in Sharma et al. [20] and Subedi et al. [22]. 


\section{Local Site Effects}

The damage intensity depends on not only the magnitude and distance to the epicenter of the earthquake but also the local soil conditions, topography and other factors. The effects of local soils and topography on the geotechnical or structural damages were manifested during the reconnaissance. This section illustrates case studies in the areas where these effects were observed.

The basin effect of Kathmandu Valley is evident from the long period ground motion recorded at KATNP station located in the core of valley (Fig. 2). Moreover, severe damage to well-designed tall buildings (high-rise apartment) in Kathmandu Valley strongly revealed the basin effect (Fig. 14). The scattering of failed high-rise apartment throughout the cities of Kathmandu, Bhaktapur, and Lalitpur implies that the damage may not be purely attributed to the poor quality construction materials or inadequate design, because similar apartment buildings with fewer stories were observed to experience much lesser damage [21]. Structural damage concentrated in a few pockets of the Kathmandu Valley such as Gongabu, Balaju, Machha Pokhari, Ramkot and Naikap might be attributed to the loose fill and young deposits [18]. Building damage was concentrated at the top of an isolated hill at Swayambhu Nath as shown in Fig. 15 which is attributed to the ground motion amplification due to ridge. The damage to the Chautara town was very severe though it is far from the epicenter and earthquake fault (Fig. 15). The reason could be the amplification of narrow mountain ridge. School building and temple are often constructed on hilltops in Nepal. Many school buildings and temples located on the top of hill were destructed (Fig. 15), might be attributed to topography effects.

When looking at the damage distribution caused by the Gorkha earthquake, one can easily notice damage concentration at or near the basin edge of the Kathmandu Valley. Towns such as Duwakot, Kapan, Manmaiju, Budhanilkantha, Jorpati, and Sankhu located at the edge of the valley basin were severely affected. Most of liquefied sites are either within or on the basin edges, regions likely to be more vulnerable to liquefaction due to basin edge effect [17].

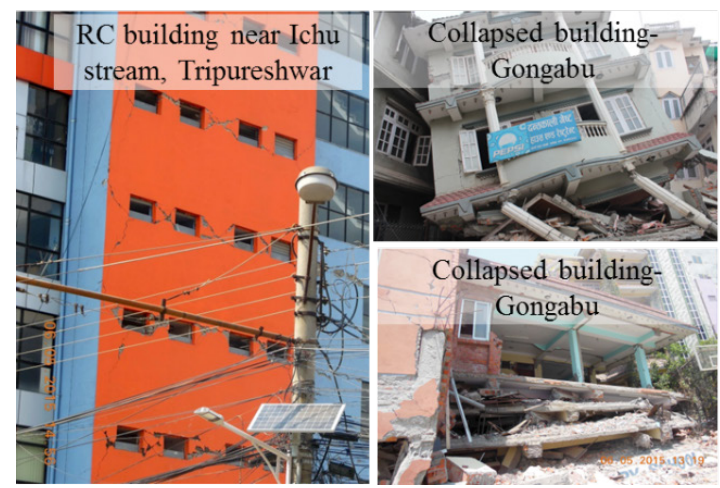

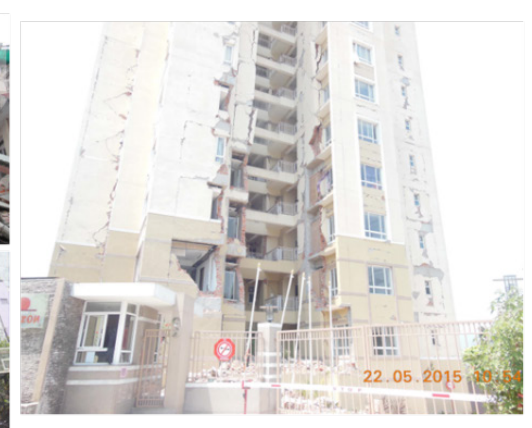

High rise building-Park View Horizon

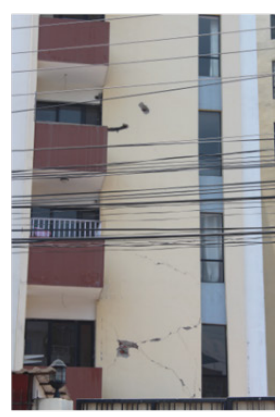

Enclave Status

Fig. 14. Severely damaged well-designed buildings
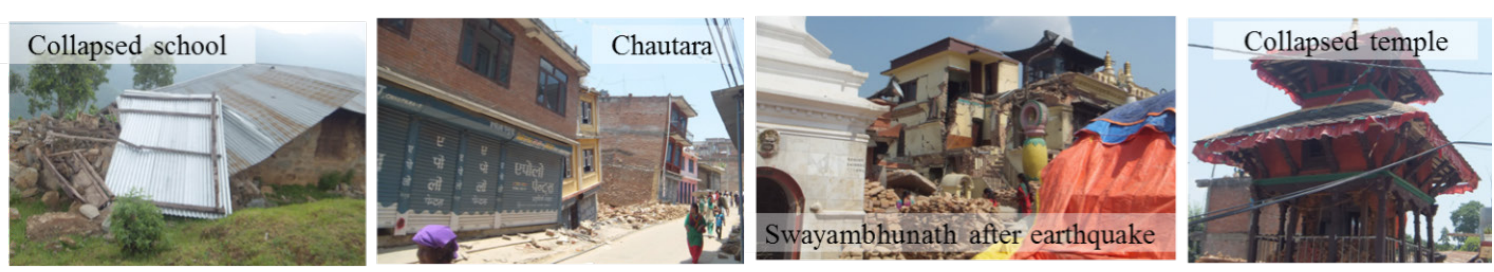

Fig. 15: Damage observed at the top of hill or along the ridge 


\section{Conclusive Remarks and Lesson Learnt}

The paper aims to investigate structural and geotechnical aspect of the 2015 Gorkha earthquake and summarises the lesson learnt from this seismic event. The following conclusion could be reached based on the reconnaissance.

1. The peak ground acceleration at a soil site in the Kathmandu Valley in horizontal direction was 184 gal. Comparison of the recorded ground motions at soil and outcrop rock sites shows a significant amplification of the response spectra at the period of $5.0 \mathrm{sec}$, due to the soft, deep sediments in the Kathmandu Valley.

2. Both poor construction practices and the continued use of non-ductile seismic detailing were the primary reasons for most of the RC building collapses. Shear reinforcement was lacking in most damaged columns observed. The common modes of failure of masonry buildings were shear failure of walls, gable wall failures, out of plane failures, and separation of walls from the roof etc. Various possible causes for the higher level of earthquake damage to the heritage structures are age of the structures, lack of regular maintenance, higher flexibility but larger masses, pre-existing damage and cracks etc. Retrofitted heritage structure and school building performed well during the earthquake.

3. A large number of slope failures and rocks fall occurred at shallow depth. Numerous ground fissures were found in devastated area. Small scale and localized liquefactions were found at several locations in Kathmandu Valley. Lifeline infrastructures including bridge performed reasonably well, with the exception in some limited areas. The damage patterns revealed strong influence of local site conditions on the severity of the damage at many places. Building damage in Kathmandu Valley and nearby villages was caused not only by the poor quality of non-engineered buildings but also by local site effects.

Researchers, practitioners, and policy makers may learn following lessens from the earthquake:

1. The 2015 Nepal earthquake highlighted the need of developing structural systems with adequate strength, stiffness, ductility, and redundancy. The importance of involving experienced engineers and enforcing code compliance at all phases of building design and construction is highlighted, as most of the structures which failed were non-engineered and vernacular construction. Earthquake resistant construction that would be suitable for the rural areas and smaller urban centers (e.g. adobe and stone masonry building) should be studied and verified scientifically.

2. This study revealed the importance of carefully considering site conditions such as soil types and topography, a factor that has not been considering in Nepal National Building Code. Hence codal provisions should emphasize strongly on geotechnical investigations and understanding the seismic behaviour of sub soil. Making risk maps for site effects makes a large contribution to risk reduction of earthquakes, e.g. the decision-making about urban planning in earthquake-prone areas. Also, there is a need for identifying the sites that are prone to strong earthquake shaking, ground failures such as landslides, fault displacements and slope failures. Determination of appropriate land use should then be guided by the identified hazards to mitigate potential loss. Microzonation mapping in Kathmandu Valley, depending on liquefaction resistance of soils should be carried out on the basis of soil type and the type of structure vulnerable to strong quakes in this area. 
3. Most critical structures such as schools, hospitals, and lifeline services especially those located on weak subsoils and site subjected to geologic hazards should be relocated or retrofitted to meet the requirement of maintaining functions after an earthquake.

4. Ground motion characteristics of this earthquake seem strange and duration is very long which demands deep insight investigation for future preparedness. A network of monitoring earthquake motions is imperative. The lack of a network makes it difficult to quantify the motions at various regions in the valley or to characterize the local site response.

Most importantly, Nepal is a country of high seismic risk and with its unique seismic characteristics, now it's urgent to invest in scientific institutions and research facilities in earthquake engineering to develop the technology to reduce the effect of earthquake in the future.

\section{References}

[1] Chaulagain H, Rodrigues H, Jara J, Spacone E and Varum H (2013), Seismic response of current RC buildings in Nepal: a comparative analysis of different design/construction. Engineering Structure, 49 : 284-294.

[2] Collins BD and Jibson RW (2015), Assessment of existing and potential landslide hazards resulting from the April 25, 2015 Gorkha, Nepal earthquake sequence. (ver. 1.1, August 2015): U.S. Geological Survey Open-File Report 2015-1142, 50 p., http://dx.doi.org/10.3133/ ofr20151142.

[3] Dixit AM, Yatabe R, Dahal RK and Bhandary NP (2013), Initiatives for earthquake disaster risk management in the Kathmandu valley. Natural Hazards, 69 (1) : 631-654.

[4] Goda K, Kiyota T, Pokhrel R, Chiaro G, Katagiri T, Sharma K and Wilkinson S (2015), The 2015 Gorkha Nepal earthquake: insights from earthquake damage survey. Frontier Built Environment, $1: 8$.

[5] Jaishi B, Ren WX, Zong ZH and Maskey PN (2003), Dynamic and seismic performance of old multi-tiered temples in Nepal. Engineering Structures, 25 (14) : 1827-1839.

[6] Japan International Cooperation Agency (JICA) (2002), The study of earthquake disaster mitigation in the Kathmandu Valley, Kingdom of Nepal. Final Report, I-IV.

[7] KC A, Sharma K and Pokharel B (2017), Performance of heritage structure in Kathmandu Valley during 2015 Gorkha Nepal earthquake. Journal of Earthquake Engineering (in press).

[8] National Seismological Center of Nepal (NSC) (2016), http://www.seismonepal.gov.np/index. php (accessed on September 1, 2016).

[9] Nepal National Building Code (NBC)-105 (1994), Nepal national building code for seismic design of buildings in Nepal, ministry of housing and physical planning, Department of Buildings, Kathmandu, Nepal.

[10] Pandey MR, Tandukar R, Avouac JP, Vergne J and Heritier T (1999), Seismotectonics of the Nepal Himalaya from a local seismic network. Journal of Asian Earth Science, 17 : 703-712.

[11] Parajuli HR, Maskey PN and Taniguchi H (2012), Vulnerability assessment of the old brick masonry buildings. Disaster Mitigation Cultural Heritage Historic Cities, 6 : 61-66

[12] Paudyal YR, Bhandary NP and Yatabe R (2012), Seismic microzonation of densely populated area of Kathmandu Valley of Nepal using microtremor observations. Journal of Earthquake Engineering, 16 : 1208-1229.

[13] Post Disaster Needs Assessment (PDNA) Nepal earthquake (2015), Post disaster needs assessment. Published by government of Nepal. www.npc.gov.np.

[14] Rana BSJB (1935), Nepal Ko Maha Bhukampa (Great Earthquake of Nepal). Second edition, 
Kathmandu.

[15] Shakya K, Pant DR, Maharjan M, Wijeyewickrema AC and Maskey PN (2012), Lessons learned from performance of buildings during the September 18, 2011 earthquake in Nepal. Asian Journal of Civil Engineering, 14 (5) : 719-733.

[16] Sharma K (2016), Field reconnaissance after the April 25, $2015 M_{w} 7.8$ Gorkha earthquake. The Proceeding of 1st NESA Symposium, University of Alberta, Alberta, Canada.

[17] Sharma K and Deng L (2016), Geotechnical engineering aspect of the 2015 Gorkha, Nepal, earthquake. The Proceeding of the 1st International Symposium on Soil Dynamics and Geotechnical Sustainability, Hong Kong, August 7-9.

[18] Sharma K and Deng L (2017), Reconnaissance report on geotechnical engineering aspect of the 2015 Gorkha, Nepal, earthquake. Journal of Earthquake Engineering: 1-26.

[19] Sharma K, Deng L and Cruz-Noguez C (2016), Field investigation on the performance of building structures during the April 25, 2015, Gorkha earthquake in Nepal. Engineering Structures, $121:$ : 61-74.

[20] Sharma K, Deng L and Khadka, D (2017), Reconnaissance of Liquefaction Case Studies in 2015 Gorkha (Nepal) Earthquake and Assessment of Liquefaction Susceptibility. International Journal of Geotechnical Engineering: 1-13.

[21] Sharma K, Subedi M, Parajuli RR and Pokharel B (2017), Effects of surface geology and topography on the damage severity during the 2015 Gorkha, Nepal earthquake. Journal of Lowland Technology International, 18 (4) : 269-282.

[22] Subedi M, Acharya IP, Sharma K and Adhikari Kalpana (2016), Liquefaction of Soil in Kathmandu Valley from the 2015 Gorkha, Nepal, Earthquake. Nepal Engineers' Association, Technical Journal- Special Issue on Gorkha Earthquake 2015, XLIII-EC (1) : 108-115.

[23] Subedi M, Sharma K, Upadhayay B, Poudel RK and Khadka P (2012), Soil Liquefaction Potential in Kathmandu Valley. International Journal of Landslides and Environment, 1(1) : 91-92.

[24] Takai N, Shigefuji M, Rajaure S, Bijukchhen S, Ichiyanagi M, Dhital MR and Sasatani T (2016), Strong Ground Motion in the Kathmandu Valley during the 2015 Gorkha, Nepal, Earthquake. Earth Planets and Space, 68 : 10. doi:10.1186/s40623-016-0383-7.

[25] UNDP/MOHPP (1994), Seismic hazard mapping and risk assessment of Nepal. United Nations Development Programme and Ministry of Housing and Physical Planning, Government of Nepal.

[26] United States Geological Survey (USGS) (2015), http://earthquake.usgs.gov/realtime/product/ finite-fault/us 20002926/us/1429969841288/20002926.html (accessed on May 27, 2015). 